\title{
Experiences of spontaneous abortion in primigravidae during the first trimester of pregnancy: a phenomenological study
}

\author{
Vivências da interrupção espontânea da gravidez em primigestas no primeiro trimestre gestacio- \\ nal: um estudo fenomenológico \\ Experiencias de la interrupción espontánea del embarazo en primerizas en el primer trimestre \\ gestacional: un estudio fenomenológico.
}

Ana Paula Forte Camarneiro*; Juraci Conceição Silveira Cardoso Maciel**;

Rosa Maria Garcia da Silveira***

\begin{abstract}
Theoretical framework: Spontaneous Abortion (SA) in primigravidae triggers complex emotional reactions that occur outside the healthcare services.

Objectives: To understand the experience of $S A$ in primigravidae during the first trimester of pregnancy.

Methodology: Qualitative and phenomenological study. The sample is purposive and composed of six participants. Data were obtained using open interviews and analysed based on Loureiro's $(2002 ; 2006)$ proposal. Both contextual reliability and transferability were ensured.

Results: The essence of the phenomenon is the shattering of a dream that results from the sudden deprivation of a desired pregnancy and motherhood. The structure found is divided into three central themes: experience of negative feelings; inner elaboration; desire to ensure motherhood. These themes coexist over time, although they manifest themselves differently. Conclusion: $\mathrm{SA}$ is an early pregnancy loss which brings about significant negative emotions and an effort of personal reorganisation, thus requiring attention and supervision by the healthcare professionals.
\end{abstract}

Keywords: spontaneous abortion; pregnancy loss; grief; obstetric nursing.

\section{Resumo}

Enquadramento: A Interrupção Espontânea da Gravidez (IEG) em primigestas desencadeia reações emocionais complexas que ocorrem fora dos serviços de saúde.

Objetivos: Compreender a vivência da IEG no primeiro trimestre de gravidez nas mulheres primigestas.

Metodologia: Estudo qualitativo, fenomenológico. A amostra, do tipo intencional, é constituída por seis participantes. A informação foi obtida por entrevista aberta e a sua análise teve por base a proposta de Loureiro (2002; 2006). Foi garantida a fidelidade e transferibilidade contextual.

Resultados: A essência do fenómeno é o desfazer do sonho que resulta da privação súbita da gravidez e da maternidade desejada. A estrutura encontrada organiza-se em três temas centrais: vivência de sentimentos negativos; elaboração interior; desejo de garantia da maternidade. Estes temas coexistem ao longo do tempo embora se manifestem com forças distintas.

Conclusão: A IEG constitui uma perda gestacional precoce, vivida com emoções negativas importantes mas também com o esforço de reorganização interior, que merece atenção e monitorização por parte dos profissionais de saúde.

Palavras-chave: aborto espontâneo; perda gestacional; luto; enfermagem obstétrica.

* Ph.D., Psychologist, Adjunct Professor, Nursing School of Coimbra, 3046-851, Coimbra, Portugal [pcamarneiro@esenfc.pt]. Contribution to the article: interview script validation and interview analysis; bibliographic search; elaboration of the literature review; intelectual critical review of the manuscript and final article writing

Address for correspondence: Rua do Açude, n. ${ }^{\circ}$ 150, Quinta da Mainça, 3020-489, Coimbra, Portugal. ** RN, Specialist in Maternal Health and Obstetrics, Hospital da Horta, 9900-451, Horta-Faial, Portugal [juracimaciel@gmail.com].Contribution to the article: interview script design; interview conduction, transcription and analysis; bibliographic search; study design, analysis and interpretation of the findings and elaboration of the manuscript together with the supervisor.

** RN, Specialist in Maternal Health and Obstetrics, Hospital da Horta, 9900-451, Horta-Faial, Portugal [silveirosa@sapo.pt]. Contribution to the article: interview script design; interview conduction, transcription and analysis; bibliographic search; study design, analysis and interpretation of the findings and elaboration of the manuscript together with the supervisor.

\section{Resumen}

Marco contextual: La interrupción espontánea del embarazo (IEG, por sus siglas en portugués) en primerizas desencadena reacciones emocionales complejas que tienen lugar fuera de los servicios de salud.

Objetivos: Comprender la experiencia de la IEG en el primer trimestre de embarazo en las mujeres primerizas.

Metodología: Estudio cualitativo y fenomenológico. La muestra, de tipo intencional, está formada por seis participantes. La información se obtuvo mediante una entrevista abierta y su análisis se basó en la propuesta de Loureiro (2002, 2006). Se garantizó la fidelidad y la transferibilidad contextual.

Resultados: La esencia del fenómeno es la desaparición del sueño que deriva de la privación repentina del embarazo y de la maternidad deseada. La estructura encontrada se organiza en tres temas centrales: experiencia de sentimientos negativos; elaboración interior, y deseo de garantía de la maternidad. Estos temas coexisten a lo largo del tiempo aunque se manifiesten con fuerzas distintas.

Conclusión: La IEG constituye una pérdida gestacional precoz, vivida con emociones negativas importantes pero también con el esfuerzo de reorganización interior, que merece una atención y monitorización por parte de los profesionales de la salud.

Palabras clave: aborto espontáneo; pérdida gestacional; luto; enfermería de la obstetricia.

Received for publication: 19.06 .14

Accepted for publication: 06.01 .15 


\section{Introduction}

The area of maternal health and obstetrics is permeated with the life and joy of the families, even though there are some unfortunate situations in the midwifery context. One of those situations is spontaneous abortion, which is an unexpected termination of pregnancy. The loss of a desired pregnancy implies many losses, such as the loss of motherhood, self-esteem, the loved one, social status and an imagined and anticipated future, especially when it is the first child (Leal, 2005; Soubieux, 2009). After a spontaneous abortion (SA), the woman experiences difficult moments of stress and significant psychological and emotional frailty (Kersting, Kroker, Schlicht, \& Wagner, 2011; Rowlands \& Lee, 2009) which should be better understood to enable better care to be provided.

In their professional practice, healthcare professionals in general and maternal health and obstetrics nurses in particular are often faced with this situation. SA is a pregnancy loss with special characteristics such as the subtle signs of pregnancy given the short gestation period, and the ethical-political controversy involving the legal status of the embryo. In these circumstances, healthcare professionals may experience difficulties in supporting or connecting with the woman or couple, thus avoiding them or limiting contact to what is strictly necessary in terms of technical care. Neither option is satisfactory both from a professional and personal.

The studies published in Portugal on the experiences of women undergoing $\mathrm{SA}$ in the first trimester of pregnancy are scarce. This theme is relevant as this phenomenon has to be understood from the point of view of the person experiencing it. In this way, the midwifery professional practice is improved by providing individualised care and helping women in this moment of their lives.

Thus, the following objective was formulated: To understand the experience of $\mathrm{SA}$ in primigravidae during the first trimester of pregnancy.

\section{Background}

Expecting a child, especially a first child, is regarded as one of the most important events in women's lives when it corresponds to a desired pregnancy and the desire of motherhood (Camarneiro \& Justo, 2010; Camarneiro, 2011). Women interiorise their maternal role and dream of having children long before pregnancy. After conceiving, the bond between mother and foetus that existed in the mother's dreams becomes real and grows stronger (Camarneiro, 2011; Keating \& Seabra, 1994).

Pregnancy is associated with the expectation of its success, i.e. the birth of the imagined baby during pregnancy. However, pregnancy does no always go as planned and, sometimes, it is suddenly terminated. The unexpected termination of pregnancy may be spontaneous or medical. A voluntary termination of pregnancy depends on the woman's decision, without a medical indication. Both cases entail the expulsion of the product of conception, i.e. an abortion, which is defined as the termination of pregnancy before 20 weeks of gestation. This is the most common loss, with a prevalence of 15 to $27 \%$ in women aged between 25 and 29 years, increasing to $75 \%$ in women older than 45 years. The risk is higher for women who have had a previous abortion (Kersting \& Wagner, 2012).

The loss situations in midwifery are called early losses. There are three types of early losses: early pregnancy loss; late pregnancy loss (stillbirth); and neonatal death. Contrary to common thought, Weiss (1998) considers early losses to be the most painful of all losses.

Thus, coping with loss after a SA is particularly complicated as it occurs almost entirely at an imaginary level, given the lack of physical evidence of the baby's existence (Rolim \& Canavarro, 2001; Soubieux, 2009). The termination of a pregnancy is filled with negative feelings of frustration, sadness, disappointment, anger, guilt, ambivalence, anxiety, and shame (Soubieux, 2009). When these feelings last for a long period of time, they may trigger anxiety attacks or depressive disorders (Kersting et al., 2011; Rowlands \& Lee, 2009). In addition, the psychological adaptation to a new pregnancy is compromised (Kersting et al., 2011).

Moulder (1994) considers that parents' suffering after a pregnancy loss depends on the intensity, consistency and degree of the emotional bond established during pregnancy, which is not directly associated with the gestation period, the meanings assigned to pregnancy and motherhood, the feeling of guilt (disabilities or harmful actions) or the fear of complications in future pregnancies. 
After the loss of the desired baby, there is a normal and adaptive grieving period. This normal grieving process is a personal effort of adapting to the profound and painful experience of a loss, which implies suffering but also the ability to find hope, comfort and significant alternatives. It is a complex, variable and non-static process, which is shaped by cultural values, norms and customs. Despite its orderly progression, the individual responses are not immutable. Although it has a sequential structure similar to a normal grieving process, the grieving process after a pregnancy loss has some specific characteristics that make it unique (Keating \& Seabra, 1994; Cabral, 2005).

\section{Research question}

The research question formulated for this study was as follows: What are the experiences of primigravidae who suffer the loss of a child by spontaneous abortion in the first trimester of pregnancy?

\section{Methodology}

Taking into account the object of study, an epistemological, comprehensive and qualitative approach with a phenomenological perspective was used.

As there are several ways to conduct a phenomenological study, this study followed Loureiro's proposal $(2002 ; 2006)$ which is based on some pioneering work carried out, for example, by Giorgi, Colaizzi and Van Kaam. Loureiro (2002; 2006) sought to combine the main aspects of Husserl's proposal and some concepts of other phenomenological approaches into a single model.

The sample was purposively selected and is composed of six participants who suffered a spontaneous abortion in their first trimester of pregnancy and were being followed at the Obstetrics and Gynaecology unit of the Hospital of Horta, island of Faial. Permission was requested to, and granted by, this Hospital to conduct the study. Participants were selected according to the following eligibility criteria: having had a spontaneous abortion less than six months ago; being primigravidae; not feeling inhibited to talk about their SA; and having good verbal expression.
The participants were previously contacted and gave their informed consent. Data confidentiality was ensured. As anonymity was impossible, the promise of confidentiality was a guarantee and the names were replaced by an identification number.

Data were collected through an unstructured interview which started with an open-ended question in which participants were asked to explore their ideas in more detail. The script was validated by the researchers and served as a guide to homogenise the interviews. The interviews were audiorecorded and notes were made on paper. The interview took place at the participants' homes, which was a place where they said they felt more comfortable, thus ensuring a communication-friendly environment. Some nondirective additional questions were made during interview in order to enable and ensure a greater fluency of speech and thought. Each interview ended when the participants believed to have exhausted the information. Each interview lasted an average of 40 minutes. Data collection by means of interviews ended when the researchers believed to have achieved content saturation.

The interviews were later reproduced in full by two of the researchers so as to prevent possible transcription errors. Two of the participants were contacted again to clarify information. After being completed, the transcription was validated by an expert who was also an experienced professor and researcher.

Data processing and analysis was based on Loureiro's proposal $(2002 ; 2006)$. It began with an intuitive and comprehensive reading of the information to grasp the essence of the phenomenon. Then, a constituent profile was formed, which entailed delineation into natural meaning units, meaning was attributed through interpretation, and central themes were established. When constructing the central themes, the convergence or divergence between meaning units was sought.

In order to validate the decomposition of the findings into constituent profiles, a researcher experienced in phenomenological research assessed the whole process, from text segmentation to the creation of a structure.

Findings and researchers were triangulated. The researchers made an equal contribution to the study of the phenomenon and the analysis of the findings, thereby creating an intersubjective consensus between the researchers and ensuring greater 
reliability. Transferability was ensured by intentionally selecting the participants who had experienced the same phenomenon and were able to discuss it. Regarding confirmability, the whole research process was structured and documented so that an auditor could assess it up to its beginning. In this way, an auditor would be able to analyse the raw information (transcribed in verbatim), as well as analyse the notes made when the natural meaning units were created, the meanings formulated, the themes, the constituent profile of each theme and the thematic index.

\section{Results and Discussion}

The essence of the phenomenon experienced by women who havehadaSAfound aftera comprehensive interpretation of the results is the shattering of a dream. It is an experience filled with nonsense that results from the sudden deprivation of a desired pregnancy and motherhood. The statements revealed that participants had a strong desire for motherhood and that, contrary to their expectations, they had lost the object of their love, "suddenly everything went wrong" (P4); "it's like everything happened the opposite way" (P1). The statements were based on the impossibility of making their wish come true, which left them with a feeling of emptiness and missed opportunity, "the desire to have a child who suddenly no longer exists" (P2) "when I got pregnant, I never thought this could happen, no one does ... I thought it was something rare" (P5). Indeed, with the development of midwifery and a decrease in perinatal mortality, the confirmation of conception makes parents almost certain that they will have a child in their arms (Cabral, 2005). However, international figures show a high percentage (about 20\%) of pregnancy losses (Kersting et al., 2011).

According to the participants, the joy of knowing they were pregnant corresponded to the fulfilment of a dream that was suddenly vanished "It's the shattering of a dream" (P6). Kersting and Wagner (2012) stated that parents usually have no time to anticipate or prepare themselves for the change caused by a spontaneous abortion. Thus, dealing with the loss during pregnancy is a complex and difficult process as it triggers a profound anguish at a time when they wished they were meeting their child (Soubieux, 2009). According to the women, the shattering of this dream can only be repaired when they are able to have their own child "I think this will never go away until I have my own child ..." (P3). Many women, as well as their partners, wish to become pregnant as soon as possible in an attempt to repair the previously failed parenthood (Soubieux, 2009).

The structure found to explain the essence of the phenomenon-theshattering of a dream -is divided into three central themes: Experience of negative feelings; Inner elaboration; Desire to ensure motherhood.

These themes coexist, albeit with different intensity over time. At an early stage immediately after the SA, the negative feelings are aggravated and, although they just lose intensity, they make way for an increasingly organised and progressive inner elaboration. The desire to ensure motherhood is constantly reawakened and becomes more significant with time and the underlying restoration of the dream (Figure 1).

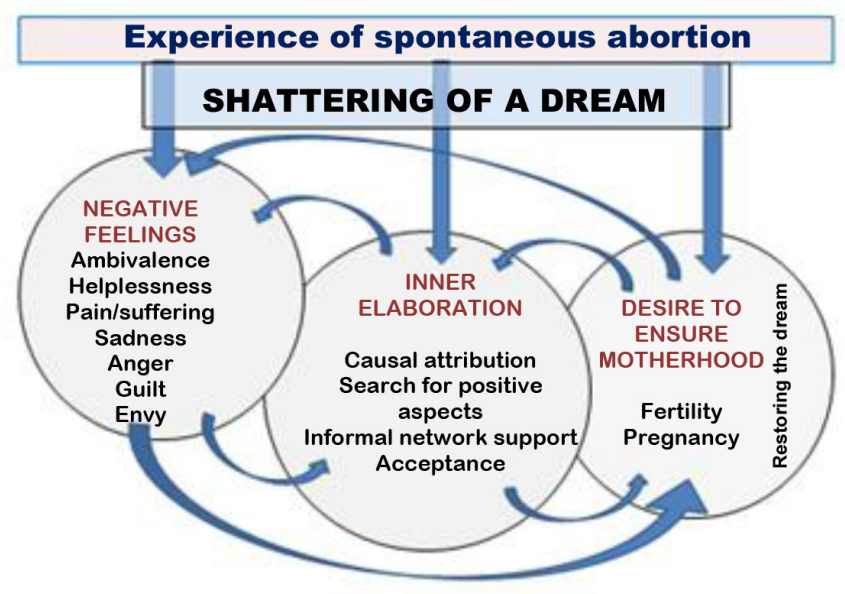

Figure 1. Comprehensive scheme of the phenomenon. 


\section{Experience of negative feelings}

Participants experience negative feelings in a disorganized and confuse way, "it's a mixture of feelings, sometimes we don't even know exactly what we feel ..." (P6). They combine ambivalence with emotional lability, "it's really hard to manage things because one moment we're really happy, the next we're sad ..." (P4), and consider the situation as something difficult to explain, "These situations bring up feelings in us that we had no idea we had ..." (P1). The feeling of helplessness as a result of the unexpected and unpredictable situation is associated with the ambivalence "it was a huge shock ..." (P5), "a tremendous disappointment ..." (P5), "like someone pulled a rug out from under our feet" (P3), leaving women highly disappointed.

The helplessness triggered a constant emotional pain/ suffering in the women "pain itself isn't just physical, it's also emotional; it's a type of pain that sticks with us, that we bring home ..." (P6). This pain can be found in every reminder of the lost motherhood and subject of love, "we have to get used to the idea that we're pregnant and then, all of a sudden, we know it's not like that anymore, that we're not pregnant, we almost have to forget that we were once pregnant ..." (P4).

The sadness felt after a SA is clearly reflected in these statements "I felt melancholic, I cried like ... yes, like a fool ... (P6)". Sadness was associated with other negative feelings, such as anger, "The biggest feeling I felt ... sadness, I really felt sad and angered. ... I guess that those were the feelings, sadness and anger ..." (P2).

In this case, the question comes up of why did the abortion happen. The participants asked themselves: "Why did this happen to me?" (P1), "Why me?" (P4). And, amidst the anger that is not always expressed, they compared themselves with women who had shown no desire for motherhood, exteriorizing their frustration for having lost a baby "so many people have children they don't want ... and I do" (P5), "It's a feeling of anger, despair, helplessness, an immense frustration ..." (P3).

In an attempt to justify their negative feelings, the participants criticised the way they were given the news, "It's the only thing that really hurt me, the way the doctor said it to me! The nurse just stood there next to me and said nothing, she just held my hand" (P3). The delivery of death news and the adequate and repeated information of its causes are essential during the shock phase and may be deeply changed by the inadequacy of the healthcare professionals who have a defensive attitude towards the parents and are able to prevent this whole process .(e.g., Canavarro, 2004; Cabral, 2005). However, according to Ferreira, Góis, Faria, and Correia (1990), the shock, disbelief, and denial seem to be an understandable attempt to escape the traumatic news that are at variance with their expectations. Hence, a crisis subsists in which there is a period of impact and an increase in tension associated with stress.

In view of these facts, the women, showing a clear sense of guilt, relentlessly sought for behaviours that may have led to the pregnancy loss, "we wonder, was it something I did ... was it because I picked up a heavy laundry basket? Or because I walked up the stairs? ..." (P3), "but why did it go wrong with me ... what did I do wrong?" (P5). In addition to these statements of guilt, women also mention divine intervention and omens of punishment and injustice. For example, they reported having dreamt of blood during the short pregnancy period, which they considered as a presage or even a prediction of abortion, "I dreamt of blood, it was an omen of abortion" (P4).

Regardless of the underlying unconscious phenomena, the experience of loss involves a grieving process with feelings of anguish and guilt (Ferreira et al., 1990; Soubieux, 2009; Walsh \& McGoldrick, 1998). In general, women tend to blame the loss on their own probelms or harmful actions. Furthermore, both anxiety and distortions of maternal fantasies are healthy mechanisms of adjustment to a new psychological balance, and may contribute to the woman's reorganisation towards the new role. By questioning guilt, primigravidae are elaborating the mourning process. They gradually begin to overcome the loss, confirming the perception that the abortion could hardly have been prevented and that its cause is often unknown, "Now I know I did nothing to cause it." (P3).

Through an interpretation of the interviews, it should be noted that the participants who reported physical signs predicting an abortion before facing the actual loss, such as physical pain and metrorrhagia, had been considering the possibility of a nonviable pregnancy. However, despite this preparatory phase, they expressed the same difficulty in accepting this outcome, perhaps because they still hoped that the 
situation would change, "I didn't want to believe what was going on... I didn't want to accept it" (P2). However, they gradually began a period of anticipatory grief, in which the shock caused by the news became less intense, although equally painful.

The confrontation with the motherhood of other women triggered feelings of envy, "I couldn't see a pregnant woman, or know that ... that someone was pregnant, I was sad. I envied them, so to speak, I envied them but in a good way. ..." (P2); "we're jealous when we see a pushchair in another woman, another situation where we wish we could be in but can't yet ..." (E6). According to Kay (1997, cit. in Cabral, 2005), the envy and jealousy towards pregnant women and mothers, as well as the avoidance of social or personal contact with women in those situations are part of the mourning process after a pregnancy loss. For these women, hearing a baby crying was an agonising experience "A baby crying ... I didn't want to be there!" (P1). In this regard, being hospitalised and sharing the same space with other pregnant women, puerperae and new-borns was a dramatic, traumatic and painful experience. The physical pain associated with the emotional pain was triggered by the contact with other pregnant women and new mothers and the confrontation with an empty cot. Kersting and Wagner (2012) stated that perinatal loss has a strong emotional impact on parents and families, leading to post-traumatic stress disorder, stress, depression, anxiety, and sleep disorders.

Underlying all the experiences describe above, it is implied that some of the feelings will fade away with the passage of time. However, the experience of abortion will never be forgotten. Letting go is not forgetting, as the loss of a loved one will someday be accepted (Cabral, 2005).

\section{Inner elaboration}

Based on the interpretation of the participants' statements, it can be concluded that the inner elaboration associated with a SA is essential for mental and maternal health. This inner elaboration is organised around a set of facilitators such as the external causal attribution, the search for positives aspects in pregnancy loss, the support of the informal network and, finally, acceptance. These organizers mitigate the experienced negative feelings discussed above.
The external causal attribution can be found, for example, in holding Nature responsible for terminating pregnancy at the right time, thereby avoiding a complicated situation later on, "instead of moving forward with this pregnancy and having a disabled child, it was better for nature to take its course and terminate the pregnancy ..." (P2). This can also be found in the participants' reference to randomness, which is justified by mentioning the frequency of SAs in other women, "lots of people have gone through the same situation ..." (P3). The external causal attribution reduced guilt and helped to ease the pain.

The search for meaningful positive aspects in pregnancy loss also facilitated the inner elaboration. The participants also considered the fact that they got pregnant as something positive since it represented a guarantee of fertility and the end of the anguish of possible sterility, "it is was very painful, I ... on the one hand I'm happy because ... at least I know I can get pregnant ... I was afraid I couldn't ..." (P5). They also considered it to be a positive aspect that the SA had occurred in an early pregnancy stage, before they could establish a stronger bond with the baby, "maybe it was better this way, better now than later on and after I could feel and see a fully formed baby, it would be harder ..." (P2).

There is no doubt that the bond between mother and child grows during pregnancy, as both pregnancy and the maternal role, which is built over time, are experienced more intensely (Camarneiro, 2011).

The participants also considered the informal network support to be a facilitator. The possibility of knowing they had someone close to them on whom they could rely was found to be a great help. They did not specify the type of relationship they had with those people but they were clearly people who were close to them and made them feel safe, "they were always there and were always ... like a safe haven" (E3). They mentioned it was positive being able to gradually talk with someone who had a similar experience. This helped them understand and see the subject under a new light, "I felt a huge need to talk ... with friends, people who have gone through the same thing ... it helped me knowing that it happens ... it's not just me ... and understanding what was happening ..." (P4). Moreover, encouraged by the rewarding aspects of dialogue, some women reported being willing to talk to others going through a similar suffering so as 
to help them overcome the loss. This can be seen, for example, in the following meaning units, "I know that if any woman ... wanted to talk to me about the abortion, I would be ready to talk and give my opinion and try to help her getting over it, but ... talking about it ... during the first few months it was hard ..." (P6).

Nery, Monteiro, Luz, e Crizóstomo (2006) state that women in general become more sensitive after an abortion and try to talk about their emotions with whoever wishes to participate in these moments of pain. Regarding the informal network, women mentioned the support they felt and the one they wished to offer. Their husband or partner is not included in that network, probably because women feel they are part of the process. Social support and good conjugal relationships have a very important role in women's adjustment after a pregnancy loss (Kersting \& Wagner, 2012).

In this study, the acceptance of the pregnancy loss begins when the painful memories start fading away and are replaced with hope for the future, "time heals everything, or at least it helps", "I'll only be able to get over this episode when I'm able to have my own child" (P2). The reference to the conviction that time is the best medicine as it helps to accept that what happened will never be forgotten is either implicit or explicit in all interviews. When talking about their experience with the passage of time, the participants reported being certain that the abortion had triggered previously unknown feelings and emotions which led to inner transformations, but not to physical changes, as they considered themselves to be physically well, "I feel good, I live a normal life, I pulled through, thank God!" (P6).

By accepting the SA, they are able to openly talk about the situation, looking at it from a different perspective and gaining self-confidence. However, when they stop to think, they relive the incident and idealise the pregnancy and the baby, "I looked at a baby and fantasised it was mine, I felt I wanted it to be mine ..." (P6). Idealisation is an obstacle to acceptance. A pregnancy loss is the loss of a baby in the mother's imagery, and it has some special features that make it unique (Cabral, 2005; Keating \& Seabra, 1994).

Despite the acceptance, the loss of the desired baby will arouse feelings of emptiness, desolation and pain in women when they are faced with the absence of the desired child. According to Walsh and McGoldrick (1998, p. 32), the loss is not simply a discrete event; it involves a transactional process over time.

Thus, coping with loss after a SA is particularly complicated as it occurs almost entirely at an imaginary level, given the lack of physical evidence of the baby's existence. In addition, "the death of a child short-circuits the normal expectation of seeing him grow and continue the family line, which is the only form of immortality for the human being" (Keating \& Seabra, 1994, p. 292). In many of these cases, women are at risk for psychological distress following a SA, thus they should attend follow-up consultations (Kersting \& Wagner, 2012).

\section{Desire to ensure motherhood}

The desire to become pregnant, ensure motherhood, and restore the dream persists and is common to all participants. They manifest, however, fear that they will go through the same suffering as before, thus postponing the decision, "the 2nd pregnancy will be lived with great anxiety, anguish and fear" (P2).

Despite this, nothing will discourage these women from wanting to get pregnant. With the passage of time, a second pregnancy is seen with optimism and hope for a happy ending; "we need to have faith, to believe that everything will be fine" (P5). According to Nery et al. (2006), women tend to look for support in the hope of becoming pregnant again, and this pregnancy will be seen as a solution to overcome the suffering. Thus, they will become progressively aware of the steps that they have already taken and, little by little, get ready for the next pregnancy. However, they know this pregnancy will never be lived with the same joy and innocence as the previous one, "It's no longer that joy that first-time mothers often feel, we have more ... fears, concerns, a feeling that it can happen again. I think it's more like that ..." (P6).

An interesting and defensive aspect that should be underlined is the reference to their good physical condition which makes them feel ready for a new pregnancy "I feel like I was before ... I have a normal menstrual cycle, I feel good, and I live a normal life." (P1). However, the experience of the next pregnancy will be influenced by the belief, although implicit, that a given behaviour may determine its failure.

Despite the fear of going through the same suffering, making them postpone the decision, they need to become pregnant and mothers to restore the lost 
dream. The doubts and concerns are a defence mechanism against more suffering in the event of a loss, and the new pregnancy is often kept secret during the first few months, as the couple has lost confidence in their ability to become parents (Soubieux, 2009). Despite the theoretical divergences regarding a pregnancy after a loss, the more conciliatory stances state that, although it is a potential obstacle to the normal course of the grieving process, it may have repairing effects on the mothers in terms of the selfdevaluation of their maternal ability and persecutory guilt (Cabral, 2005; Soubieux, 2009).

\section{Conclusion}

Pregnancy losses are a public health issue and require special attention by the healthcare professionals as they may lead to a wide range of emotional disorders in the woman, the couple and the siblings. Nurses and specialist nurses in maternal health and obstetrics are in the front line of care provision to these women and are able to monitor the grieving process associated with the experience of a SA.

However, the experience of a SA depends on the expectations of women towards pregnancy and motherhood. If those expectations are positive, the dream is shattered in a traumatic process associated with the deprivation of the subject of love, thus triggering various negative feelings, and a need for an inner elaboration and a guarantee of motherhood.

SAs are not always seen as significant event in the couple's life by society, family, and friends because it is difficult for them to imagine that parents already have a strong bond with their child before birth. However, the manifestations of loss and grief after the SA are considered as an affirmation of the bond between the woman and her baby during the gestation period. Therefore, the respect for the feelings expressed by women and their husbands/partners should be promoted.

Although these results do not apply to all women who experienced a SA, they can be generalised to similar contexts due to the contextual transferability.

Pregnancy loss is a complex process, and both the woman and the couple should be cared for from a multidisciplinary perspective. Caring for women going through a grieving process after a SA should be a challenge in healthcare.

\section{References}

Cabral, I. P. (2005). Morte e luto na gravidez e puerpério. In Isabel Leal, Psicologia da gravidez e da parentalidade (pp. 49-59). Lisboa, Portugal: Fim de Século.

Camarneiro, A. P. (2011). Vinculação pré-natal e organização psicológica dos homens e das mulheres no segundo trimestre de gestação (Tese de Doutoramento). Faculdade de Psicologia da Universidade de Lisboa, Portugal.

Camarneiro, A. P. \& Justo, J. (2010). Padrões de vinculação pré-natal (Contributos para a adaptação da Maternal and Paternal Antenatal Attachment Scale em casais durante o $2^{\circ}$ trimestre de gravidez, na região centro de Portugal). Revista Portuguesa de Pedopsiquiatria, 28, 7-22.

Canavarro, M. C. (2004). Vinculação, perda e luto: Implicações clínicas. Psychologica, 35, 35-47.

Ferreira, L. M., Góis, G. M., Faria, M. C., \& Correia, M. J. (1990). O Luto por morte perinatal e/ou malformação do bebé. Análise Psicológica, 4(8), 399-402.

Keating, I. \& Seabra, M. J. (1994). Luto e vinculação. Análise Psicológica, 2-3(12), 291-300.

Kersting, A., Kroker, K., Schlicht, S., \& Wagner, B. (2011). Internetbased treatment after pregnancy loss: Concept and case study. Journal of Psychosomatic Obstetrics and Gynecology, 32(2), 72-78. Doi: 10.3109/0167482x2011.553974

Kersting, A. \& Wagner, B. (2012). Complicated grief after perinatal loss. Dialogues in Clinical Neuroscience, 14(2), 187-194.

Leal, I. (Cord.). (2005). Psicologia dagravideze daparentalidade. Lisboa, Portugal: Fim de Século.

Loureiro, L. M. J. (2002). Orientações teórico-metodológicas para aplicação do método fenomenológico na investigação em enfermagem. Revista de Enfermagem Referência, 8, 5-16.

Loureiro, L. M. J. (2006). Adequação e rigor na investigação fenomenológica em enfermagem: Crítica, estratégias e possibilidades. Revista de Enfermagem Referência, 2(2 Série), 21-31.

Moulder, C. (1994). Towards a preliminary framework for understanding pregnancy loss. Journal of Reproductive and Infant Psychology, 12(1), 65-67.

Nery, I. S., Monteiro, C. F. S., Luz, M. H. B., \& Crizóstomo, C. D. (2006). Vivências de mulheres em situação de aborto espontâneo. Revista de Enfermagem UERJ, 14(1), 67-73.

Rolim, L. \& Canavarro, M. C. (2001). Perdas e luto durante a gravidez e puerpério. In Maria Cristina Canavarro, Psicologia da gravidez e da maternidade (pp.255-296). Coimbra, Portugal: Quarteto Editora.

Rowlands, I. \& Lee, C. (2009). Correlates of miscarriage among young women in the australian longitudinal study on women's health. Journal of Reproductive and Infant Psychology, 27(1), 40-53. 
Soubieux, M. J. (2009). Le deuil périnatal. Bruxelles, Belgique: Temps d'arrête.

Walsh, F. \& McGoldrick, M. (1998). Morte na família: Sobrevivendo às perdas. Porto Alegre, Brasil: Artes Médicas.
Weiss, R. S. (1998). Issues in the study of loss and grief. In J. H. Harvey (Ed.), Perspectives on Loss: A sourcebook. New York, USA: Brunner/Mazel. 
